\title{
The Effect Of Motivation And Organizational Climate On Specialist Doctors's Loyalty In Prima Medan Royal Hospital
}

\author{
Mulya $^{1}$, Tan Suyono ${ }^{2 *}$, Ali Napiah Nasution ${ }^{3}$, Adek Amansyah ${ }^{4}$ \\ $1,2,3,4$ Universitas Prima Indonesia \\ ${ }^{*}$ Corresponding Author: \\ Email: tansuyono@unprimdn.ac.id
}

\begin{abstract}
.
The role of specialist doctors in hospital services is large, making the bargaining position of specialist doctors high against hospitals. Various literature states that loyalty plays an important role in the formation of a person's decision in choosing a place of work and giving commitment. This study analyzes the effect of motivation and organizational climate on the loyalty of specialist doctors. This explanatory survey research uses a crosssectional design. The study was conducted at the Royal Prima General Hospital Medan for 1 (one) month starting from July 2021 to August 2021. The sample was 50 people who were determined by the inclusion criteria were specialist doctors who had worked for at least 2 years. Data were analyzed using the Chi-Square test and multiple logistic regression. The results of statistical tests using Chi-Square show that motivation has a significant effect on the loyalty of specialist doctors, whereas the results of statistical tests show that physical and esteem needs have a p-value of less than 0.05. The organizational climate also affects the loyalty of specialist doctors, where the results of statistical tests show that flexibility, responsibility, standards, and commitment have $p$ values less than 0.05. The results of the multiple logistic regression test show that the variable that has the greatest influence on the loyalty of specialist doctors is flexibility. With an Exp (B) value of 18,444 (95\%CI 2,052- 165,779), Respondents who stated good flexibility had 18 times more loyal than those who stated poor flexibility. In conclusion, good flexibility will increase the loyalty of specialist doctors. This study concludes that motivation and organizational climate have a significant effect on the loyalty of specialist doctors. The aspect of flexibility in the organizational climate has the most influence on the loyalty of specialist doctors.
\end{abstract}

Keywords: motivation, organizational climate, loyalty, specialist doctor

\section{INTRODUCTION}

Specialist doctors are health workers whose existence is at the forefront of hospital services. The existence and adequacy of specialist doctors is part of the effort to fulfill the community's need for specialist health services so that it will increase public access to quality health services. The Ministry of Health's BPPSDMK data shows that the ratio of specialist doctors has met the target of the health workforce development plan with a ratio of 13.6 per 100,000 population (target $10.4 / 100,000$ ). However, if referring to Permenkes No. 56 of 2014 concerning Hospital Classification 
and Licensing, government hospitals still require a minimum of 482 pediatricians, 369 obstetrics gynecology specialists, 408 internal medicine specialists, 571 surgeons, 173 anesthesiologists, 469 radiology specialists, 388 doctors clinical pathology specialist (Susyanty et al., 2020).The phenomenon of employee loyalty has increased recently and has become a top priority in most organizations. Most of the organizations do not want to lose employees, especially those who are very talented and highly skilled (Rishipal \& Manish, 2013). Likewise with hospitals, retaining specialist doctors is a challenge.

The important role of specialist doctors in the development of hospitals goes hand in hand with the individual needs they want to fulfill, both in the form of material and non-material provision (Sirili et al., 2018). This is expected to lead to loyalty of health workers. Preko \& Adjetey (2013) research shows that employee loyalty and performance have a relationship. Employee loyalty plays an important role in employee performance at work, employees try to give their best at work.Arvidson \& Axelsson (2017) suggest that management needs to balance the interests of the company and meet the needs of employees to increase employee loyalty. Loyalty is expressed in an employee's intention to stay in the organization for a long time, even when receiving a more attractive salary from another organization. Rishipal \& Manish (2013) argue that organizations need loyal employees to attract loyal clients/customers. Loyal and enthusiastic employees will work with dedication and produce goods and services of the highest quality. The highest quality products and services will generate loyal customers, which is a very significant and crucial factor in performance management.Hospital management must be able to motivate health workers in hospitals. Good motivation determines the formation of productive and professional human resources.

Saleh \& Katuse's research (2017) shows that factors that influence employee retention include financial incentives, career development and management issues. These things are related to the motivation of health workers. Recognition is also very influential on the motivation of health workers. Several studies also show that incentives are significantly related to the motivation and loyalty of health workers. Adequate incentives have an impact on higher satisfaction because it really helps them to support their family (Kalk et al., 2010: Fox et al., 2014).The results of the study also show that a comfortable organizational climate is one of the considerations for someone choosing a place to work (Permarupan et al., 2013: Yasa et al., 2021). When working, health workers are influenced by the organizational climate. If the organizational climate does not support a sense of comfort in working, then health workers will certainly look for alternatives to work in other places that may be more comfortable for them. The organizational climate in which they work, such as good relationships with fellow employees, superiors and subordinates will make health workers more motivated at work. 
Research by Liou \& Cheng (2010) concluded that organizational climate affects the level of commitment of health employees up to $60 \%$. Health care workers tend to decide to leave their jobs because of considerations of trustworthiness, information flow, and leadership style. Research shows a positive and significant correlation between organizational commitment and organizational climate (Bahrami et al., 2016).The results of a preliminary survey conducted at the end of June 2021, researchers met 10 patients and conducted brief interviews. 8 patients complained about the services of specialist doctors which were considered less than optimal and less friendly. They argue that specialist doctors do not pay attention to the schedule of service hours, and do not visit every day, so many inpatients complain. Some went home at their own request or transferred to another hospital. This has an impact on the achievement of the BOR (Bed Occupancy Rate) in 2021, which is $51.5 \%$ (below the standard 60-85\%).

\section{LITERATURE REVIEW}

\subsection{Customer Loyalty}

According to Hasibuan (2011) loyalty or loyalty is one of the elements used in employee assessment which includes loyalty to his job, position and organization. This loyalty is reflected by the willingness of employees to maintain and defend the organization inside and outside of work from irresponsible people. Steers \& Porter (1983) argues that loyalty is an attitude, namely the extent to which an employee identifies with his or her workplace which is indicated by the desire to work and try their best. Loyalty as behavior, namely the process by which an employee makes a definite decision not to leave the company if he does not make extreme mistakes. Robbins (2007) argues that loyalty is a process that arises as a result of the desire to be loyal and devoted to his work, group, superior or to his company, this causes a person to be willing to sacrifice to satisfy other parties or society. Loyalty is an employee's mental attitude that is shown in the company's existence. Employee loyalty has a positive impact on employee performance, employee loyalty can be seen from employee performance.

According to Saydam (2005), loyalty indicators are:

a. Obedience or compliance is the ability of an employee to obey all applicable official regulations and obey official orders given by superiors.

b. Responsibility is the ability of an employee to complete the work assigned to him properly, on time, and dare to take risks for decisions made or actions taken.

c. Devotion, namely the contribution of thoughts and energy sincerely to the company.

d. Honesty is the harmony between what is said or done with reality

\subsection{Motivation}

Motivation is the driving force that causes a member of the organization to be willing and willing to mobilize abilities in the form of expertise or skills, energy and time to carry out various activities that are their responsibility and fulfill their 
obligations in the context of achieving the goals and various organizational goals specified (Siagian, 2004). Gitosudarmo \& Sudita (1997) stated that there are two kinds of motivation or encouragement for employees to be willing to work together in order to achieve common goals or company goals, namely: (a) financial motivation, namely encouragement carried out by providing financial rewards to employees. These rewards are often called Incentives; and (b).

non-financial motivation namely encouragement that is manifested not in financial form, but in the form of things such as praise, appreciation, a human approach and so on. Maslow (1954) states that humans have various needs and tries to encourage them to move to meet these needs. Hersey \& Blanchard (2004) argues, motivation is a driving force that includes encouragement, reason and will that arises in a person that causes him to do something, for example an employee who receives a salary, the reward is in accordance with the educational qualifications he has, then his work loyalty will increase. . Work motivation can positively affect employee work loyalty. In short, it can be interpreted that there is an influence of motivation on loyalty. Employee motivation is directly proportional to employee work loyalty. If employee motivation is high, then loyalty is high, and vice versa

\subsection{Organizational Climate}

According to Davis \& Newstrom (1996): "Organizational climate is the environment in which employees of an organization do their jobs. Climate surrounds and affects everything that works in the organization so that climate is said to be a dynamic concept. Meanwhile, according to Simamora (2004), organizational climate consists of relationships between employees and a combination of values and goals set by the company. Simamora sees the organizational climate as a synergy between the relationship between employees and the values and goals set by the company. According to Gibson et al. (2003) used the term organizational climate to describe the environment or situation of the organization.

The term organizational climate can also be used to describe the psychological climate or organizational personality which is "a set of environmental conditions that are felt directly or indirectly by employees." Mathis et al. (2015) explains that organizational climate is the feeling of employees towards the company and the aspects in it. Research on climate rganization can be used to identify the changes needed for the progress of the company. Meanwhile, Nitisemito (2000) argues that organizational climate is everything that is around the workers that can influence them in carrying out the tasks assigned. Organizational climate is largely determined by the attitude of management towards the organization and how the relationship between employees and between groups within an organization. Based on the descriptions above, it can be concluded that organizational climate is a dynamic concept that can affect employees and organizations in their activities at work. 


\section{METHODS}

This type of research is an explanatory survey designed to explain the causal relationship between variables through hypothesis testing, aiming to determine the effect of motivation and organizational climate on the loyalty of specialist doctors at the Royal Prima General Hospital Medan. The design used in this study was crosssectional. The population in this study were all specialist doctors who served at Royal Prima Medan General Hospital totaling 88 people. The sample in this study was selected using purposive sampling method. Purposive sampling is a sampling technique with certain considerations according to research needs. Inclusion criteria in determining the sample are specialist doctors who have worked at least 2 years at Royal Prima General Hospital Medan. After conducting the research, the sample size was 50 people, so the total sample was 50 specialist doctors. The data that has been entered into the computer will be statistically analyzed on the computer. Data analysis was performed using univariate, bivariate and multivariate analysis.

\section{RESULT AND DISCUSSION}

\subsection{Results}

Before testing the hypothesis, the goodness of fit is first calculated, namely to find out whether the regression model is fit. Hypothesis test using Hosmer and Lemeshow test. Based on the Hosmer and Lomeshow test, the Chi Square test value was 4.487 with $\mathrm{p}=0.722>\mathrm{p}=0.05$. This means that the regression model is fit or feasible. This means that motivation and organizational climate variables can be used to predict loyalty variables.

Table 1. Hosmer and Lemeshow Test

\begin{tabular}{cccc}
\hline Step & Chi-square & df & Sig. \\
\hline 1 & $\underline{4,487}$ & $\underline{7}$ & $\underline{0,722}$ \\
\hline
\end{tabular}

Based on the Nagelkerke R-square coefficient, it was found that the seven predictors of motivation and organizational climate variables were able to explain $60.0 \%$ of the total diversity of loyalty and the remaining $40.0 \%$ was explained by other factors outside the model.

Tabel 2. Overall Model Assessment Results Regresi

\begin{tabular}{ccc}
\hline Step & Cox \& Snell R Square & Nagelkerke $R$ Square \\
\hline 1 & 0,448 & 0,600
\end{tabular}

Multivariate analysis of multiple logistic regression models must meet the test results requirements. The requirement is that the independent variable indicator included in the multivariate test must have a $\mathrm{p}$ value of $<0.25$ in the bivariate test. Based on the results of the bivariate test using the Chi-Square method, all variables are eligible to be included in the multivariate test because they have a $\mathrm{p}$ value $<0.25$. 
Table 3. Multiple Logistics Regression Test Results

\begin{tabular}{lccccc}
\hline Variabel & B & Sig. & Exp $(B)$ & \multicolumn{2}{c}{ 95\%CI for Exp $(B)$} \\
\cline { 5 - 6 } & & & & Lower & Upper \\
\hline Physical needs & 1,746 & 0,161 & 5,733 & 0,500 & 65,682 \\
Appreciation needs & 0,383 & 0,771 & 1,467 & 0,111 & 19,415 \\
Actualization needs & 1,628 & 0,086 & 5,096 & 0,792 & 32,779 \\
Flexibility & 2,915 & 0,009 & 18,444 & 2,052 & 165,779 \\
Responsibility & 1,586 & 0,107 & 4,885 & 0,710 & 33,628 \\
Standard & 1,492 & 0,095 & 4,447 & 0,771 & 25,642 \\
Commitment & 1,375 & 0,155 & 3,953 & 0,596 & 26,240 \\
Constant & $-18,097$ & 0,001 & 0,000 & & \\
\hline
\end{tabular}

\subsection{Discussion}

\subsubsection{The Effect of Physical Needs on the Loyalty of Specialist Doctors}

The results showed that the univariate physical needs in the high category were 36 people $(72.0 \%)$. This illustrates that specialist doctors still prioritize meeting physical needs first in providing services. The respondent's reason for saying this is because specialist doctors have to cover the daily needs of the family, so they continue to carry out the cooperation agreement with the hospital even though it is not fully in line with the expectations of the specialist. Specialist doctors individually provide services to inpatients only to the extent of their responsibility not fully aware that providing services to patients is the duty of a doctor (general practitioner, dentist and specialist) in accordance with Law no. 29 of 2004 concerning Medical Practices (UUPK) which regulates the limitation of 3 places of practice, it is hoped that specialist doctors can provide quality services to patients (Government of Indonesia, 2004).

Based on the results of interviews, specialist doctors stated that providing services to inpatients is the responsibility of specialist doctors, but because of the busyness in serving daily patients, specialist doctors have not placed the interests of patients as the main priority, so they seem disloyal to the hospital. This is related to the busyness of a specialist in work related to productive age, as many as $92.0 \%$, aged 3555 years (middle adults). Mark et al. (2017) concluded that aging is associated with a decrease in human functional capacity, both physical function and cognitive function. The relationship between age and performance has also been studied in the general population. Studies on French volunteers who participate in activities show differences in physical fitness and performance as measured by differences in the age of volunteers (Nassif et al., 2012).

When viewed by age, specialist doctors at Royal Prima General Hospital Medan, middle age specialists (40-45 years) and transitional fifties (50-55 years) are more loyal, meaning that senior specialists are more loyal than junior specialists. The results of the bivariate test showed that the motivation for physical needs was significantly related to the loyalty of specialist doctors in providing services to patients $(\mathrm{p}<0.05)$.Hospital management needs to make efforts to increase some of the physical 
needs, because the unfulfilled physical needs are one of the main reasons respondents are not loyal to cooperate with hospitals. Specialists are of the opinion that the medical services received have not fully met the physical needs of specialists. If viewed based on the hospital rate set by the board of directors, this hospital in setting rates cannot be separated from the hospital's vision and mission, so the rate setting does not only depend on revenue requirements alone. Research by Lihawa et al. (2016) show that emerging work motivation can increase doctor loyalty. Management must also consider individual needs in increasing psychological satisfaction. Work motivation is the responsibility of the hospital management. The management does not need to pay attention to individual characteristics in an effort to improve the performance of doctors.

\subsubsection{The Influence of the Need for Appreciation on the Loyalty of Specialist Doctors}

The results showed that univariately the need for appreciation in the category was 38 people (76.0\%). This illustrates that most of the specialist doctors working at Royal Prima General Hospital Medan stated that the award from the hospital was quite good. Specialist doctors not only pursue physical needs in serving patients, but specialists also need appreciation needs. The need for appreciation is related to the hospital management's attention to the needs of specialist doctors, the lack of attention from hospital management has an impact on the loyalty of specialists to the hospital as an organization. The results of the bivariate test showed that the motivation of the need for appreciation was significantly related to the loyalty of specialist doctors in providing services to patients $(\mathrm{p}=0.029)$ and it was found that from 38 respondents who stated the need for high appreciation there were as many as 18 people are disloyal and as many as 20 people are loyal.

The existence of an award is one of the main reasons respondents are loyal to work with hospitals. Specialists are of the opinion that in addition to fulfilling physical needs through medical services received by specialists, they also need to fulfill the need for appreciation. The Mosadeghrad study (2014) identified nine organizational factors that influence physician motivation, namely salary, work environment, managerial leadership, organizational policies, co-workers, recognition, job security, job identity, and opportunities for promotion. The reward system built by management is very important in managing human resources which is the most valuable asset of an organization. Giving rewards to employees will attract, retain, and motivate workers (Agwu, 2013). Rewards in the form of performance recognition, flexible working hours, opportunities for training and career development are key factors in managing health human resources (James et al., 2015).

\subsubsection{The Influence of the Need for Actualization on the Loyalty of Specialist Doctors}

The results showed that univariately the need for actualization in the low category was 29 people $(58.0 \%)$. This illustrates that most of the specialist doctors who 
work at Royal Prima General Hospital Medan are less in need of actualization. The reason the respondent stated this was because specialist doctors did not consider it a priority. It can be seen from the respondents' answers that most of the respondents disagreed about collaborating with hospitals, which is a sense of pride and given the opportunity to submit ideas for performance achievement, so that it has an impact on the loyalty of specialists to the hospital as an organization. The results of the bivariate test showed that the motivation for actualization needs was not significantly related to the loyalty of specialist doctors in providing services to inpatients $(\mathrm{p}>0.05)$ and it was found that of the 29 respondents who stated that the need for actualization was low there were 19 people $(67.9 \%)$ disloyal category and as many as 10 people $(45.50 \%)$ loyal.

Fulfilling the need for actualization is not a priority of the respondent's motivation which causes disloyalty to cooperate with the hospital. Specialists believe that the need for appreciation from hospitals and colleagues is more important to them as a form of appreciation for their performance. In this study, it was found that the motivation of specialist doctors to work together in private hospitals was largely due to the importance of fulfilling physical needs before fulfilling the motivation of appreciation and actualization. Maslow (1943) suggests that people will try to meet basic needs before trying to meet higher needs. Needs do not arise together at the same time (Dawlatly, 2014). Increasing employee loyalty is made possible by overcoming perceptions of employee reward fairness which is achieved through increased reward satisfaction. The results provide a clear indication to the HR bureau of the need to redesign reward practices to include perceptions of employee reward fairness to optimize employee loyalty (R. et al., 2020). In short, it can be interpreted that there is an influence of motivation on loyalty.

\subsubsection{The Effect of Flexibility on the Loyalty of Specialist Doctors}

The results showed that univariate flexibility in the good category was 33 people $(66.0 \%)$. Flexibility is the flexibility to act for specialist doctors in making adjustments to the tasks given in providing services to patients. This illustrates that specialist doctors have a perception that communication between specialist doctors and management on policies made by the hospital has been running in harmony. The cooperation agreement with the hospital has been carried out even though it has not fully met the expectations of the specialist. The results of the bivariate test showed that the flexibility aspect of the organizational climate was significantly related to the loyalty of specialist doctors in providing services to inpatients $(p<0.05)$. The results of the multivariate test using logistic regression showed that the flexibility aspect of the organizational climate was the only one that had a significant effect on the loyalty of specialist doctors with an Exp (B) value of 18.444. This means that respondents who state good flexibility are 18 times more likely to be loyal than those who state that flexibility is not good. In conclusion, good flexibility will increase the loyalty of 
specialist doctors. Specialists are of the opinion that they have not fully complied with all the rules and regulations that apply to specialist doctors in hospitals.

Some respondents stated that individually providing services to inpatients is not permanent (on site) and not all hospital rules can be fulfilled because they are busy serving daily patients to meet the needs of daily life and have not put the patient's interests as the main priority. However, good flexibility makes them loyal so that it has an impact on disloyalty to the hospital.Another assumption is that respondents are disloyal, limited possibilities for double practice. The reasons for dual practice (practicing in several hospitals) may be quite diverse at the individual level, and it is possible that each doctor has very different personal career expectations and goals (Johannessen \& Hagen, 2014). Studies show the dual practice of specialist doctors is a multidimensional problem, influenced by various factors such as financial incentives, cultural attitudes, and available infrastructure (Bayat et al., 2018). Work loyalty will be created if employees feel fulfilled in meeting the needs of life in their work, so that they feel at home working in a company such as fulfilling work facilities, welfare reviews, work atmosphere and wages received from the company.

\subsubsection{The Effect of Responsibility on the Loyalty of Specialist Doctors}

The results showed that the univariate responsibilities in the bad and good categories were quite balanced with the same number of 25 people each $(50.0 \%)$. Responsibility is the responsibility of the specialist for the results achieved in providing services to patients. This illustrates that some specialist doctors are not fully responsible for providing services to inpatients. The reason respondents stated this was because they were busy serving patients every day, so that the agreed schedule was sometimes not fully fulfilled by specialist doctors on time. The results of the bivariate test showed that the organizational climate of the responsibility aspect was significantly related to the loyalty of specialist doctors in providing services to inpatients $(\mathrm{p}<0.05)$. Some specialist doctors are of the opinion that because they work part-time in hospitals in providing services, they have not been able to fully comply with all the rules and regulations that apply to specialist doctors.

Based on the results of interviews with specialist doctors that individually providing services to inpatients is not permanent and hospital management does not set achievement targets in serving patients, so it has an impact on disloyalty to the hospital, but specialist doctors do not agree if called specialist doctors are not responsible in serving patients, so that most specialists disagree on questions about targets or achievements. Specialists play a role as a medical expert, communicator, collaborator, manager, health advocate, scholar, and professional in providing health services. Leadership and collaboration within the clinical team, accountability for clinical outcomes, responsibility to provide specialist medical care and appropriate management of community resources are key attributes (Committee of President Medical Colleges, 2014). The diverse roles and responsibilities of specialist doctors make this profession quite vital in the continuity of health services at the secondary 
level. Awareness of specialist doctors is needed to carry out their role as secondary service providers (Djuwantono, 2012).

\subsubsection{The Effect of Standards on Specialist Loyalty}

The results showed that the standard univariate in the good category was 31 people $(62.0 \%)$. The results of the bivariate test showed that the standard aspect of the organizational climate was significantly related to the loyalty of specialist doctors in providing services to inpatients $(\mathrm{p}<0.05)$ and it was found that 31 respondents who stated good standards were 14 people $(50.0 \%)$. loyal category and as many as 17 people $(77.3 \%)$ are not loyal. It can be seen that a good standard will also have a good impact on the loyalty of specialist doctors. Standards are provisions or provisions required by hospital management for specialist doctors in providing services to patients. In order to maintain the quality of service, the hospital management sets service standards for its human resources, for example setting the service time. In this study, the clarity of the standards set by the hospital is related to the loyalty of specialist doctors. Certainty standards and regulations are important references for specialist doctors in carrying out their duties, understanding their rights and obligations can clarify their position.

Discussions on the need to develop regulation (standardization) for certain routine procedures that are essential to achieving the targeted results, have started several decades ago. The arrangement of activities and procedures carried out by doctors aims to provide greater safety for patients. It is also useful to prevent doctors from the possibility of errors (malpractice) and complaints from patients (Shestopalova and Gololobova, 2018). Guarantees to work according to standards and procedures create a sense of security for doctors in carrying out their activities. Loyalty will increase along with feelings of respect felt by HR. Research shows good working conditions and career opportunities are essential for building stable employment and professional development. Employees respond to good organizational support with organizational commitment and high psychological attachment, obligation, and loyalty (Tomic et al., 2018).

\subsubsection{The Effect of Commitment to Loyalty of Specialist Doctors}

The results showed that the univariate commitment in the bad category was 26 people $(52.0 \%)$. Commitment is a feeling of attachment or willingness of specialist doctors to the hospital, which is marked by the willingness to work in the hospital and willing to follow the regulations in the hospital in providing services to patients. This illustrates that most specialist doctors are not fully committed to providing services to inpatients. The results of the bivariate test showed that the organizational climate of the commitment aspect was significantly related to the loyalty of specialist doctors in providing services to inpatients $(\mathrm{p}<0.05)$ and it was found that from 26 respondents who stated that commitment was not good there were 19 people $(67.9 \%)$ disloyal category and 7 people $(31.8 \%)$ loyal. Commitment is one of the obstacles for a specialist doctor causing disloyalty to the hospital. Specialists are of the opinion that 
because they work part-time at the hospital in providing services, they are not fully able to work optimally, instill a sense of belonging and can obey all the rules and regulations that apply in the hospital. Research by Al-Hussami et al. (2014) show that commitment and quality improvement in the workplace is a good strategy to reduce the intention of health workers to switch workplaces.

Employees who are highly committed will voluntarily engage in work without questioning organizational rewards, and are more likely to empower their physical and material abilities (Rusu, 2019).

Organizational climate can be explained through a combination of top management values and goals, certain underlying policies as well as the implementation and implementation of those policies. If the top management of an organization lacks integrity and cannot be trusted and does not care about employees, then such an attitude will have an impact on the entire organization. On the other hand, if top management demonstrates its commitment to good human relations and supports various company functions and programs and policies related to human resource management, it is likely that this climate can be created and maintained. The results of this study are in line with the theory of Gibson et al. (2003) stated that organizational climate is the quality of the internal environment that is relatively ongoing, experienced or felt by members of the organization, influencing the behavior of each member of the organization. Organizational climate is a number of conditions or conditions in a series that directly or indirectly, consciously or unconsciously affect employee performance and have an impact on work loyalty.

\section{CONCLUSIONS AND RECOMMENDATION}

\subsection{Conclusion}

1. Motivation has a significant effect on the loyalty of specialist doctors, where the results of statistical tests show that physical needs and esteem needs have a p-value of less than 0.05 .

2. Organizational climate affects the loyalty of specialist doctors, where the results of statistical tests show that flexibility, responsibility, standards, and commitment have $\mathrm{p}$ values less than 0.05 .

3. The results of the multiple logistic regression test show that the variable that has the greatest influence on the loyalty of specialist doctors is flexibility. With an $\operatorname{Exp}(\mathrm{B})$ value of $18,444(95 \% \mathrm{CI} 2,052-165,779)$, it can be said that respondents who stated good flexibility had 18 times more loyalty than those who stated poor flexibility. In conclusion, good flexibility will increase the loyalty of specialist doctors.

\subsection{Suggestion}

\section{For Royal Prima Hospital Medan}

Hospital management needs to make efforts to improve the loyalty of specialist doctors and monitor and evaluate the work of specialist doctors on an ongoing basis in order to improve the performance and quality of service to patients by using the 
potential resources available at the hospital through the fulfillment of work facilities, review welfare, work atmosphere and medical services received from the hospital.

\section{For other researchers}

To be able to research the recruitment and retention of specialist doctors.

\section{REFERENCES}

[1] Agwu, M., 2013. Impact of Fair Reward System on Employees Job Performance in Nigerian Agip Oil Company Limited Port-Harcourt. Br. J. Educ. Soc. Behav. Sci. 3, 47-64. https://doi.org/10.9734/bjesbs/2013/2529

[2] Al-Hussami, M., Darawad, M., Saleh, A., Hayajneh, F.A., 2014. Predicting nurses' turnover intentions by demographic characteristics, perception of health, quality of work attitudes. Int. J. Nurs. Pract.

20, 79-88. https://doi.org/https://doi.org/10.1111/ijn.12124

[3] Arep, I., Tanjung, H., 2003. Manajemen Motivasi. Gramedia, Jakarta.

[4] Arvidson, M., Axelsson, J., 2017. Exploring self-loyalty in the context of social acceleration: theorising loyalties as emotions and resistance. J. Polit. Power 10, 133148. https://doi.org/10.1080/2158379X.2017.1335835

[5] Azwar, A., 2000. Pengantar Administrasi Kesehatan, 3rd ed. Binarupa Aksara, Jakarta.

Bahrami, M.A., Barati, O., Ghoroghchian, M., Montazer-alfaraj, R., Ranjbar Ezzatabadi, M., 2016. Role of Organizational Climate in Organizational Commitment: The Case of Teaching Hospitals. Osong Public Heal. Res. Perspect. 7,96-100. https://doi.org/https://doi.org/10.1016/j.phrp.2015.11.009

[6] Bayat, M., Shokri, A., Khodadost, M., Fattahi, H., Mirbahaeddin, E., Harirchi, I., Akbari-Sari, A., Zalani, G.S., Khalilnezhad, R., 2018. Factors influencing medical specialists' dual practice in the Islamic republic of Iran. East. Mediterr. Heal. J. 24, 877-887. https://doi.org/10.26719/2018.24.9.877

[7] Cashman, C., 2010. Occupational and Environmental Medicine. Occup. Med. (Chic. Ill). 60, 239. https://doi.org/10.1093/occmed/kqp173

[8] Committee of President Medical Colleges, 2014. Strategic Position Statement: The Role of The Medical Specialist.

[9] Davis, K., Newstrom, J.W., 1996. Perilaku Organisasi, 1st ed. Erlangga, Jakarta. Dawlatly, S.L., 2014. Do our consultation models meet our patients' needs? Br. J.

[10] Gen. Pract. 64, 245. https://doi.org/10.3399/bjgp14X679787

[11] Djuwantono, T., 2012. Peran Dokter Spesialis Dalam Pelayanan Kesehatan Masyarakat.

[12] Fox, S., Witter, S., Wylde, E., Mafuta, E., Lievens, T., 2014. Paying health workers for performance in a fragmented, fragile state: reflections from Katanga Province, Democratic Republic of Congo. Health Policy Plan. 29, 96-105. https://doi.org/10.1093/heapol/czs138

[13] Gibson, J.L., Ivancevich, J.M., Donnelly, J.H., Konopaske, R., 2003. Organization: Behavior, Structure, and Processes, 11th ed. McGraw-Hill, New York. 
[14] Gitosudarmo, I., Sudita, N.I., 1997. Perilaku Keorganisasian. BPFE-Yogyakarta, Yogyakarta.

[15] Handoko, T.H., 2001. Manajemen Personalia dan Sumber Daya Manusia. BPFEYogyakarta, Yogyakarta.

[16] Hasibuan, M.S.P., 2011. Manajemen Sumber Daya Manusia, 13th ed. Penerbit Bumi Aksara, Jakarta.

[17] Hersey, P., Blanchard, K.H., 2004. Management of Organizational Behavior:Utilizing. Prentice Hall, New Jersey.

[18] Jacobalis, S., 2000. Rumah Sakit Indonesia Dalam Dinamika Sejarah, Transformasi, Globalisasi Dan Krisis Nasional. Yayasan Penerbitan IDI, Jakarta.

[19] James, O.E., Ella, R., S.E, N., E. Lukpata, F., Lazarus Uwa, S., Awok Mbum, P., 2015. Effect of reward system among health care workers performance: a case study of university of Calabar teaching hospital Calabar, Nigeria. J. Hosp. Adm. 4, 45. https://doi.org/10.5430/jha.v4n3p45

[20] Johannessen, K.A., Hagen, T.P., 2014. Physicians' engagement in dual practices and the effects on labor supply in public hospitals: Results from a register- based study. BMC Health Serv. Res. 14, 1-11. https://doi.org/10.1186/1472- 6963-14-299

[21] Kalk, A., Paul, F.A., Grabosch, E., 2010. "Paying for performance" in Rwanda: does it pay off? Trop. Med. Int. Heal. 15, 182-190. https://doi.org/10.1111/j.13653156.2009.02430.x

[22] Kelner, S., 1998. Managing the Climate of a TQM Organization. Cent. Qual.Manag. J. 7, 31-37.

[23] Kolb, D.A., Rubin, I.M., 1984. Organizational Psychology an Experiental Approach to Organizational Behavior. Prentice Hall Inc, New Jersey.

[24] Leinster, S., 2014. Training medical practitioners: which comes first, the generalist or the specialist? J. R. Soc. Med. 107,

99-102. https://doi.org/10.1177/0141076813519438

[25] Lihawa, C., Noermijati, N., Rasyid, H. Al, 2016. Pengaruh Motivasi Kerja terhadap Kinerja Dokter dalam Kelengkapan Pengisian Rekam Medis dengan di Moderasi Karakteristik Individu (Studi di Rumah Sakit Islam Unisma Malang).J.Apl.Manaj.14, 300-308. https://doi.org/10.18202/jam23026332.14.2.12

[26] Liou, S.-R., Cheng, C.-Y., 2010. Organisational climate, organisational commitment and intention to leave amongst hospital nurses in Taiwan. J. Clin. Nurs. 19, 16351644. https://doi.org/https://doi.org/10.1111/j.1365- 2702.2009.03080.x

[27] Luthans, F., 2006. Perilaku Organisasi, 10th ed. Andi Publisher, Yogyakarta. Marck, A., Berthelot, G., Foulonneau, V., Marc, A., Antero-Jacquemin, J., Noirez,

[28] P., Bronikowski, A.M., Morgan, T.J., Garland Jr, T., Carter, P.A., Hersen, P., Di Meglio, J.-M., Toussaint, J.-F., 2017. Age-Related Changes in Locomotor Performance Reveal a Similar Pattern for Caenorhabditis elegans, Mus domesticus, Canis familiaris, Equus caballus, and Homo sapiens. Journals Gerontol.Ser.A72,455463. https://doi.org/10.1093/gerona/glw136

[29] Maslow, A., 1954. Motivation and Personality. Harper \& Row, New York. Mathis, R.L., Jackson, J.H., Valentine, S.R., 2015. Human Resource

[30] Management: Essential Perspectives, 7th ed. OH: Southwestern College, Cincinnati. 
[31] Mosadeghrad, A.M., 2014. Factors affecting medical service quality. Iran. J. Public Health 43, 210-220.

[32] Muninjaya, G., 2011. Manajemen Mutu Pelayanan Kesehatan. EGC, Jakarta.

[33] Nassif, H., Sedeaud, A., Abidh, E., Schipman, J., Tafflet, M., Deschamps, T., Maillet, H., Ovigneur, H., Desgorces, F.-D., Toussaint, J.-F., 2012. Monitoring fitness levels and detecting implications for health in a French population: an observational study. BMJ Open 2, e001022. https://doi.org/10.1136/bmjopen-2012-001022

[34] Nitisemito, A.S., 2000. Manajemen Personalia: Manajemen Sumber Daya Manusia. Ghalia Indonesia, Jakarta.

[35] Pemerintah Indonesia, 2004. Undang-Undang No. 29 Tahun 2004 tentang Praktik Kedokteran.

[36] Permarupan, P.Y., Mamun, A. Al, Saufi, R.A., Zainol, N.R.B., 2013. Organizational climate on employees 'work passion: A review. Can. Soc. Sci. 9, 63-68. https://doi.org/10.3968/j.css.1923669720130904.2612

[37] Preko, A., Adjetey, J., 2013. A Study on the Concept of Employee Loyalty and Engagement on the Performance of Sales Executives of Commercial Banks in GHANA. Int. J. Bus. Res. Manag. 4, 51.

[38] R., H. V, Subramoniam, S., M., N.H., 2020. Redesigning Rewards for Improved Fairness Perception and Loyalty. Vision 24, 481-495. https://doi.org/10.1177/0972262920946142

[39] Rishipal, Manish, 2013. Performance Management and Employee Loyalty. Glob. J. Manag. Bus. Res. 13.

[40] Robbins, S.P., 2007. Perilaku Organisasi Jilid I, 12th ed. Salemba Empat, Jakarta. Rusu, R., 2019. Organizational Commitment and Characteristics of the

[41] Workplace. L. Forces Acad. Rev. 24, 297-302. https://doi.org/10.2478/raft- 20190037

[42] Saleh, A., Katuse, P., 2017. Factors Influencing Retention of Essential Healthcare Providers At Facility Level in Mandera County: A Case Study of Mandera County Referral Hospital, Kenya. East African Heal. Publ. Thesis Hub 2, 1- 21.

[43] Saydam, G., 2005. Manajemen Sumber Daya Manusia: Suatu Pendekatan Mikro. Djambatan, Jakarta.

[44] Schermuly, C.C., Draheim, M., Glasberg, R., Stantchev, V., Tamm, G., Hartmann, M., Hessel, F., 2015. Human resource crises in German hospitals- an explorative study. Hum. Resour. Health 13, 1-10. https://doi.org/10.1186/s12960-015-0032-4

[45] Shestopalova, T.N., Gololobova, T. V., 2018. Standard operating procedures as a trend in ensuring healthcare safety. Heal. Risk Anal. 2018, 129-137. https://doi.org/10.21668/health.risk/2018.2.15.eng

[46] Siagian, S.P., 2004. Teori Motivasi dan Aplikasi. Rineka Cipta, Jakarta. Simamora, H., 2004. Manajemen Sumber Daya Manusia, 2nd ed. STIE YKPN, Yogyakarta.

[47] Sirili, N., Frumence, G., Kiwara, A., Mwangu, M., Anaeli, A., Nyamhanga, T., Goicolea, I., Hurtig, A.K., 2018. Retention of medical doctors at the district level: A qualitative study of experiences from Tanzania. BMC Health Serv. Res. 18, 1-10. https://doi.org/10.1186/s12913-018-3059-0

[48] Steel, R., Vaughan, C., 1994. The Treatment You Deserve: The Right Way to Get It from the New NHS. Constable \& Robinson Limited, London. 
[49] Steers, R.M., Porter, L.W., 1983. Motivational and Work Behavior. McGraw Hill Book Company, New York.

[50] Stringer, R., 2005. Leadership and Organizational Climate. Prentice Hall, New Jersey.

[51] Susyanty, A.L., Hendarwan, H., Su'udi, A., 2020. Incentive Distribution of Specialist Doctors in Government General Hospital. J. Penelit. dan Pengemb. Pelayanan Kesehat. 4, 69-79.

[52] Tomic, I., Tesic, Z., Kuzmanovic, B., Tomic, M., 2018. An empirical study of employee loyalty, service quality, cost reduction and company performance. Econ. Res.Istraživanja31, 827-846. https://doi.org/10.1080/1331677X.2018.1456346

[53] Trisnantoro, L., 2005. Aspek Strategis Manajemen Rumah Sakit Antara Misi Sosial dan Tekanan Pasar. Andi Publisher, Yogyakarta.

[54] Yasa, I.G.G.U., Gunadi, I.G.N.B., Suarjana, I.W., 2021. Pengaruh Kepemimpinan, Motivasi, Dan Iklim Organisasi Terhadap Komitmen Organisasi Karyawan Pada PT Praja Bali Transportasi. Values 2, 433-444. 